\title{
Purification and Characterization of an Elastolytic Protease of Vibrio vulnificus
}

\author{
By MAHENDRA H. KOTHARY AND ARNOLD S. KREGER* \\ Department of Microbiology and Immunology. The Bowman Gray School of Medicine of Wake \\ Forest University, Winston-Salem, North Carolina 27103, USA
}

(Received 10 November 1986; revised 24 February 1987)

Large amounts of a highly purified, extracellular elastolytic protease of Vibrio vulnificus were obtained by sequential ammonium sulphate precipitation and hydrophobic interaction chromatography with phenyl-Sepharose CL-4B. The protease had an $M_{\mathrm{r}}$ of about 50500 (estimated by SDS-PAGE), a pI of 5.7, and a temperature optimum range of 55 to $60^{\circ} \mathrm{C}$. The $\mathrm{pH}$ optimum and the results of inactivation studies suggested that the enzyme was a neutral metalloprotease. The protease had about 429 amino acid residues, and the first 20 aminoterminal amino acid residues were Ala-Gln-Ala-Asn-Gly-Thr-Gly-Pro-Gly-Gly-Asn-Ser-LysThr-Gly-Arg-Tyr-Glu-Phe-Gly. The purified protease was toxic for mice (about $1.5 \mathrm{mg} \mathrm{kg} \mathbf{~}^{-1}$ and $4.5 \mathrm{mg} \mathrm{kg}^{-1}$, intraperitoneal and intravenous $\mathrm{LD}_{50}$ values, respectively), and subcutaneous injection of the enzyme elicited rapid and extensive dermonecrosis.

\section{INTRODUCTION}

The halophilic bacterium Vibrio vulnificus is an opportunistic pathogen that is an aetiological agent of rapidly developing, life-threatening wound infections and septicemia in humans (Wickboldt \& Sanders, 1983; Tison \& Kelly, 1984; Morris \& Black, 1985). Putative virulence factors produced by $V$. vulnificus include $(a)$ extracellular products, such as a lethal cytolytic toxin (Kreger \& Lockwood, 1981; Gray \& Kreger, 1985), phospholipases (Testa et al., 1984), siderophores (Andrus et al., 1983; Simpson \& Oliver, 1983), and proteases (Carruthers \& Kabat, 1981: Poole et al., 1982; Smith \& Merkel, 1982; Kothary \& Kreger, 1985b), and (b) a surface antigen(s) that confers resistance to phagocytosis and the bactericidal activity of normal serum (Kreger et al., 1981; Amako et al., 1984: Yoshida et al., 1985) and possesses protective antigen activity (Kreger et al., 1984). Our interest in the extracellular proteases of the bacterium was prompted by the possibility that they may be responsible, at least in part, for the extensive local tissue necrosis often observed during wound infections caused by $V$. vulnificus. We have reported previously (Kothary \& Kreger, 1985b) that V. vulnificus ATCC 29307 produces only one extracellular protease in a medium composed of $2 \%(\mathrm{w} / \mathrm{v})$ Proteose Peptone (Difco) and $1.5 \%$ $(\mathrm{w} / \mathrm{v})$ sodium chloride, and that the protease is produced in large amounts and is elastolytic. The studies in this paper $(a)$ extend our previous studies by describing a simple procedure for obtaining large amounts of highly purified elastase, and $(b)$ use the highly purified elastase to confirm and advance our knowledge concerning the physicochemical and biological properties of the enzyme.

\section{METHODS}

Assays. Protease activity against azocasein was determined as previously described (Kothary \& Kreger, $1985 b$ ). Elastase activity of the fractions obtained by hydrophobic interaction chromatography was estimated by a previously described plate diffusion procedure (Kothary \& Kreger, 1985b). Elastase activity of the step 3 protease

Abbreviations : PBS-DM-AA, phosphate-buffered saline supplemented with nonfat dry milk and Antifoam A; OPA, orthophenanthroline 
preparation and in the determination of $\mathrm{pH}$ optimum studies was estimated by assaying against elastin-Congo red (Sigma) as previously described (Kothary \& Kreger, 1985b), except that the incubation period was $20 \mathrm{~min}$. One unit of elastase activity is the amount of enzyme which hydrolyses $1 \mathrm{mg}$ elastin-Congo red in $20 \mathrm{~min}$ at $37^{\circ} \mathrm{C}$.

Protein was estimated by the method of Bradford (1976) with bovine gamma globulin as the standard. The standard and the assay reagent were obtained from Bio-Rad.

Purification of protease. The culture supernatant fluids (step 1 preparation) from three Proteose Peptone broth cultures (about $450 \mathrm{ml}$ of culture) of V. vulnificus ATCC 29307 (designated strain A8694 by the Centers for Disease Control, Atlanta, Ga., USA), and the ammonium sulphate-precipitated enzyme preparation (step 2 preparation) were obtained as previously described (Kothary \& Kreger, 1985 $\mathrm{b}$ ). The step 2 preparation contained in $2.5 \mathrm{ml}$ of 100 mM-ammonium bicarbonate ( $\mathrm{pH} \mathrm{7.8)}$ was fractionated by hydrophobic interaction chromatography with phenyl-Sepharose CL-4B (Pharmacia) as previously described (Kothary \& Kreger, 1985b), except the gel was washed with 15 bed vols $10 \%(\mathrm{v} / \mathrm{v})$ ethylene glycol in $100 \mathrm{mM}$-ammonium bicarbonate rather than with 7 bed vols of buffer before eluting the enzyme with $30 \%$ ethylene glycol $(\mathrm{v} / \mathrm{v})$ in $100 \mathrm{~mm}$-ammonium bicarbonate. The six fractions comprising the peak of eluted activity were pooled (step 3 preparation) and were stored at $-60^{\circ} \mathrm{C}$.

Antisera. New Zealand White rabbits $(2.5 \mathrm{~kg})$ were injected subcutaneously with $0.5 \mathrm{ml}$ water-in-oil emulsion containing $10 \mathrm{mg}$ dry wt (about 200 protease units) of a lyophilized step 2 protease preparation dissolved in water and emulsified with 2 vols complete Freund adjuvant. The rabbits were injected subcutaneously 4 and 8 weeks later with a similar emulsion prepared with incomplete Freund adjuvant. The rabbits were exsanguinated about 3 weeks after the last injection, and the anti-step 2 serum was lyophilized and stored at $4^{\circ} \mathrm{C}$.

Antiserum against the purified step 3 protease preparation was prepared by a modification of the procedure described by Harboe \& Closs (1983), which involves vaccinating rabbits with an immunoprecipitate that is obtained by crossed immunoelectrophoresis and contains the desired antigen. Three samples $(60 \mu \mathrm{g}$ total protein) of the step 3 protease were subjected to crossed immunoelectrophoresis with the anti-step 2 serum. The three gels were washed and pressed, and each of the three precipitin arcs containing the protease was cut out of the gels. The three pooled precipitin arcs were mixed with $0.6 \mathrm{ml} \mathrm{PBS}\left(20 \mathrm{mM}-\mathrm{Na}_{2} \mathrm{HPO}_{4}, 150 \mathrm{mM}-\mathrm{NaCl}\right.$; adjusted to $\mathrm{pH} 7.4$ with $\mathrm{HCl}$ ) and the mixture was sonically disrupted in an ice-bath with a Branson Sonifier (model 185) until the agarose gel had visibly been dispersed. A water-in-oil emulsion was prepared by emulsifying the sonicated preparation with 2 vols incomplete Freund adjuvant, and New Zealand White rabbits were injected subcutaneously with $1 \mathrm{ml}$ of the emulsion. The rabbits were similarly vaccinated again 4 weeks later and were exsanguinated about 3 weeks after the second injection. The serum was lyophilized and stored at $4{ }^{\circ} \mathrm{C}$. The specificity of the anti-step 3 serum was examined by crossed immunoelectrophoresis as described below and in the legend to Fig. 1. Briefly, samples $(18 \mu \mathrm{l})$ containing $200 \mu \mathrm{g}$ and $20 \mu \mathrm{g}$ of the step 2 and step 3 protease preparations, respectively, were electrophoresed in the first dimension without serum and were electrophoresed in the second dimension against the anti-step 3 serum and the anti-step 2 serum. The specificity of the anti-step 3 serum was determined by comparing the number of precipitin arcs obtained with the anti-step 3 serum to those obtained with the anti-step 2 serum.

Crossed immunoelectrophoresis. This was done with the LKB 2117-401 immunoelectrophoresis kit. The general methodology described by Høiby \& Axelsen (1983) and in the LKB instruction manual and application note 249 (Wallenborg \& Andersson, 1978) was followed.

Results from preliminary crossed immunoelectrophoretic analyses of the step 2 preparation suggested that the protease partially digested some of the precipitin arcs. Therefore, subsequent crossed immunoelectrophoresis of the step 2 preparation was done in the presence of a protease-inhibiting concentration $(20 \mathrm{mM})$ of orthophenanthroline [OPA (Sigma)].

Slab SDS-PAGE. This was done by a modification (Gray \& Kreger, 1985) of the method described by Laemmli (1970). Two different conditions were used to denature the protease preparations before electrophoresis. In one series of experiments, the enzyme specimens were denatured by heating with SDS before electrophoresis (Gray \& Kreger, 1985) and, in a second series of experiments, enzyme preparations were inactivated and denatured at $4{ }^{\circ} \mathrm{C}$ by a modification of the procedure described by Gardi and Lungarella (1984). Briefly, trichloroacetic acid and sulphosalicylic acid were added to a sample of the step 3 preparation (about $550 \mu \mathrm{g}$ protein in $480 \mu \mathrm{l}$ ) to a final concentration of $11.5 \%$ and $3.5 \%(\mathrm{w} / \mathrm{v})$, respectively. The solution was kept for $1 \mathrm{~h}$ at $4{ }^{\circ} \mathrm{C}$, and the precipitated protease was recovered by centrifugation $(5100 \mathrm{~g}, 20 \mathrm{~min})$ and suspended in $10 \mathrm{ml} 25 \%(\mathrm{v} / \mathrm{v})$ ethanol and $8 \%(\mathrm{v} / \mathrm{v})$ acetic acid. After $16 \mathrm{~h}$ at $4{ }^{\circ} \mathrm{C}$, the precipitate was recovered by centrifugation and dissolved in $0.55 \mathrm{ml}$ of the running buffer (25 mM-Tris, $192 \mathrm{mM}$-glycine, 0.1\% SDS; pH 8.3) used for SDS-PAGE. The preparation was boiled for $2 \mathrm{~min}$ with disruption solution containing SDS, $\beta$-mercaptoethanol, and glycerol as previously described (Gray $\&$ Kreger, 1985), and samples $(30 \mu \mathrm{g})$ were loaded onto the gel.

The $M_{\mathrm{r}}$ of the denatured and reduced step 3 protease was estimated by the relative mobility method of Weber $e t$ al. (1972), using the slab SDS-PAGE protocol described above. $M_{\mathrm{r}}$ standards were obtained from Pharmacia.

Western blot analysis. Step 3 protease preparations were subjected to SDS-PAGE and the separated protein bands were electrophoretically transferred $\left(0.3 \mathrm{~A}\right.$ and $60 \mathrm{~V}$ at $10^{\circ} \mathrm{C}$ for $\left.4 \mathrm{~h}\right)$ to nitrocellulose strips (Bio-Rad) using 
$25 \mathrm{mM}$-Tris buffer containing $192 \mathrm{mM}$-glycine and $20 \%$ (v/v) methanol, as described by Towbin et al. (1979). After electrophoretic transfer, the nitrocellulose strips were gently washed with PBS. Some strips were stained with Amido Black, and other strips were gently agitated for $2 \mathrm{~h}$ at $25^{\circ} \mathrm{C}$ in PBS containing $5 \%(\mathrm{w} / \mathrm{v})$ nonfat dry milk and $0.001 \%$ Antifoam A (PBS-DM-AA), washed three times ( 5 min each wash) with PBS, and incubated with primary antibody $\left(1: 30\right.$ dilution of anti-stage 3 serum in PBS-DM-AA) for $4 \mathrm{~h}$ at $25^{\circ} \mathrm{C}$ with gentle agitation. The strips were washed three times with PBS and incubated with secondary antibody $[1: 1000$ dilution of goat antirabbit IgG-horseradish peroxidase conjugate (Bio-Rad)] in PBS-DM-AA for $1 \mathrm{~h}$ at $25^{\circ} \mathrm{C}$ with gentle agitation. The strips were washed four times with PBS and immersed in Tris-buffered saline ( $50 \mathrm{mM}$-Tris, $250 \mathrm{~mm}$ $\mathrm{NaCl}$; adjusted to $\mathrm{pH} 7.5$ with $\mathrm{HCl})$ containing $\mathrm{H}_{2} \mathrm{O}_{2}(0.018 \%$, v/v) and 4-chloro-n-naphthol $(0.06 \%$, w/v; Bio$\mathrm{Rad}$ ) until colour developed at $25^{\circ} \mathrm{C}$ (5 to $20 \mathrm{~min}$ ); the strips were then rinsed with water to stop colour development. Control strips were incubated either with the secondary antibody or substrate alone.

Analytical isoelectric focusing. Analytical thin-layer isoelectric focusing in polyacrylamide gel was done with an LKB 2117 Multiphor electrophoresis apparatus and commercial polyacrylamide gel plates (pH 3.5 to 9.5) as recommended by the manufacturer.

Amino acid analyses. A sample of the step 3 protease was dialysed against $50 \mathrm{~mm}$-ammonium bicarbonate for $16 \mathrm{~h}$ at $4{ }^{\circ} \mathrm{C}$ and was lyophilized. Another sample of the step 3 protease was concentrated and transferred into 100 mM-ammonium bicarbonate with a Centricon-30 microconcentrator (Amicon). The amino acid composition of the lyophilized preparation and the amino-terminal amino acid sequence of the concentrated preparation were determined as previously described (Gray \& Kreger, 1985) for the $V$. vulnificus cytolysin.

Determination of pH optimum and stability. A sample of a step 3 protease preparation freed of ethylene glycol and transferred into $100 \mathrm{~mm}$-ammonium bicarbonate with a Centricon-30 microconcentrator was used to determine the pH optimum of the enzyme, the stability of the enzyme at various $\mathrm{pH}$ values, and the sensitivity of the enzyme to heat and to various metal ions and enzyme inhibitors as previously described for the partially purified enzyme (Kothary \& Kreger, 1985b).

Determination of temperature optimum. Samples $(20$ to $100 \mu \mathrm{l})$ of a step 3 protease preparation $\left(2\right.$ units $\left.\mathrm{ml}^{-1}\right)$ freed of ethylene glycol were added to assay mixtures containing azocasein substrate solution $(0.5 \mathrm{ml})$ and $1 \mathrm{ml}$ of $100 \mathrm{mM}$-Tris/ $\mathrm{HCl}$ buffer (pH 7.5), and activity was assayed by incubating the mixture for $10 \mathrm{~min}$ at $25,30,37,40$, $45,50,55,60,65,70$ and $75^{\circ} \mathrm{C}$.

Toxicity studies. The step 3 protease was concentrated and transferred into $100 \mathrm{mM}$ - Tris/ $\mathrm{HCl}$ buffer $(\mathrm{pH} 7.5)$ with a Centricon-30 microconcentrator. Groups of female, 6 to 8 weeks old (about $30 \mathrm{~g}$ ), CD-1 strain, randomly bred albino mice (Charles River Laboratories) ( 10 mice per group) were injected intraperitoneally or intravenously with portions $(0.1 \mathrm{ml})$ of the protease preparations diluted with buffer. The $L D_{s_{0}}$ values were estimated by the method of Reed \& Muench (1938) after observing the mice for $3 \mathrm{~d}$ postinjection. Also, mice were injected subcutaneously with portions $(0.1 \mathrm{ml})$ of the diluted protease preparations and were examined for dermonecrosis $3 \mathrm{~h}$ postinjection.

\section{RESULTS AND DISCUSSION}

\section{Purification of protease}

The quantitative results of the purification scheme are summarized in Table 1. The hydrophobic interaction chromatography step was similar to the procedure described earlier (Kothary \& Kreger, 1985b), except that the gel was washed with 15 bed vols $10 \%$ (v/v) ethylene glycol in $100 \mathrm{~mm}$-ammonium bicarbonate rather than with 7 bed vols of buffer. Comparison of fused rocket immunoelectrophoresis patterns of the fractions obtained by the two procedures indicated that the protease preparation was homogeneous only when the gel was washed with 15 bed vols of buffer (data not shown). The specific activity against azocasein and the recovery of the protease in three different step 3 preparations ranged from 237 to 250 units $\mathrm{mg}^{-1}$ and 45 to $50 \%$, respectively. In addition, the step 3 protease had about 120 units of elastase activity $\mathrm{mg}^{-1}$. The specific activity of the step 3 protease preparation was only about $50 \%$ more than the specific activity of the culture supernatant fluids (step 1 preparation). However, the results of stability studies indicated that the relatively small increase observed in specific activity was real and did not reflect significant inactivation of the enzyme during purification. Thus, the more plausible explanation for the small apparent increase in specific activity during enzyme purification is that the step 1 preparation contained relatively small amounts of contaminating proteins capable of reacting with the Bradford reagent and, therefore, their removal did not cause a large increase in specific activity during enzyme isolation. A similar situation has been observed during the purification of a Serratia marcescens protease (Lyerly \& Kreger, 1979) and a Vibrio damsela cytolysin (Kothary \& Kreger, 1985a). 
Table 1. Purification of extracellular elastolytic protease produced by $V$. vulnificus

$\begin{array}{cccccc}\text { Fractionation step } & \begin{array}{c}\text { Volume } \\ (\mathrm{ml})\end{array} & \begin{array}{c}\text { Total } \\ \text { units }\end{array} & \begin{array}{c}\text { Total } \\ \text { protein } \\ (\mathrm{mg})\end{array} & \begin{array}{c}\text { Specific } \\ \text { activity } \\ \left(\text { units } \mathrm{mg}^{-1}\right)\end{array} & \begin{array}{c}\text { Yield } \\ (\%)\end{array} \\ \begin{array}{c}\text { 1. Culture supernatant } \\ \text { fluids }\end{array} & 410 & 12710 & 80 & 159 & 100 \\ \begin{array}{c}\text { 2. Ammonium sulphate } \\ \begin{array}{c}\text { precipitation } \\ \text { 3. Hydrophobic interaction } \\ \text { chromatography }\end{array}\end{array} & 3.4 & 11900 & 57.5 & 207 & 94 \\ & 23 & 6210 & 26.2 & 237 & 49\end{array}$

* Determined with azocasein substrate

The step 3 protease preparation was homogenous by crossed immunoelectrophoresis (Fig. $1 a$, b) and analytical thin-layer isolectric focusing (Fig. 2). The weak mobility of the purified step 3 enzyme during crossed immunoelectrophoresis (Fig. $1 b$ ) most likely was caused by interaction of the enzyme with the agarose gel, and the enhanced mobility of the enzyme in the step 2 preparation (Fig. $1 a, c$ ) could have resulted from the contaminants in the preparation interfering with the enzyme-agarose interaction. In that regard, we have observed (data not shown) that when the standard, electrophoresis grade agarose (Bio-Rad) used to prepare the gel shown in Fig. $1(b)$ was replaced with ultra-pure, DNA grade agarose (Bio-Rad), the mobility of the step 3 protease was markedly enhanced and was similar to that observed in Fig. $1(a, c)$. The elastase produced by Pseudomonas aeruginosa and the cytolytic toxin of $V$. vulnificus also interact with and exhibit weak mobility in agarose gels during immunoelectrophoresis (Kreger \& Gray, 1978; Gray \& Kreger, 1985). Also, we observed previously (Kothary \& Kreger, 1985b) that the $V$. vulnificus elastase interacts with and exhibits zone broadening during gel filtration with Sephadex G-100, a dextran-based gel.

Results of SDS-PAGE analysis of the step 3 protease preparation showed that the electrophoretic patterns of the preparation were influenced by the conditions used to denature the enzyme before electrophoresis (Fig. $3 a$ ). Preparations that were inactivated and denatured at $4{ }^{\circ} \mathrm{C}$ before heating with SDS and $\beta$-mercaptoethanol showed only one band having a $M_{\mathrm{r}}$ of about 50500, but preparations that were not inactivated at $4{ }^{\circ} \mathrm{C}$ before heating and electrophoresis exhibited two major bands with $M_{\mathrm{r}}$ values of about 50500 and 42000 and a minor band with an $M_{\mathrm{r}}$ of about 9000 . In addition, step 2 preparations that were inactivated and denatured at $4{ }^{\circ} \mathrm{C}$ before heating with SDS and $\beta$-mercaptoethanol showed the band with an $M_{\mathrm{r}}$ of about 50500 but did not show the two bands with $M_{\mathrm{r}}$ values of 42000 and 9000 (data not shown). Our observations suggested that the 42000 and $9000 M_{\mathrm{r}}$ components were fragments generated by autodigestion of the enzyme. In that regard, Western blot analysis of the three bands observed with a step 3 protease preparation that was not inactivated at $4{ }^{\circ} \mathrm{C}$ before heating with SDS and $\beta$-mercaptoethanol showed that all three bands reacted with rabbit serum raised against the step 3 protease preparation (Fig. $3 b$ ). A comparison of the precipitin patterns obtained by crossed immunoelectrophoresis of the step 2 and step 3 protease preparations with the anti-step 2 and anti-step 3 sera indicated that the anti-step 3 serum was specific for the enzyme. Multiple precipitin arcs were observed when the anti-step 2 serum was tested with the step 2 protease preparation (Fig. $1 a$ ); however, only one precipitin arc was visible when the antistep 3 serum was tested with the step 2 (Fig. 1c) and step 3 protease preparations (data not shown). Thus, the results of the Western blot analysis support the idea that the 42000 and $9000 M_{\mathrm{r}}$ components are fragments of the enzyme molecule rather than contaminants.

The Western blot analysis of the step 3 protease preparation also revealed two faint bands with $M_{\mathrm{r}}$ values $>50500$ (Fig. $3 b$, lane 2). The $M_{\mathrm{r}}$ values of these bands are identical to those of two Coomassie-blue-staining bands observed during SDS-PAGE analysis of a step 3 protease preparation that was not denatured by heating or by acid treatment at $4{ }^{\circ} \mathrm{C}$ (data not shown). Thus, we believe that the faint bands $\left(M_{\mathrm{r}}>50500\right)$ in the immunoblot are minute amounts of protease aggregates present because of insufficient heating of the protease preparation before SDS-PAGE analysis. 

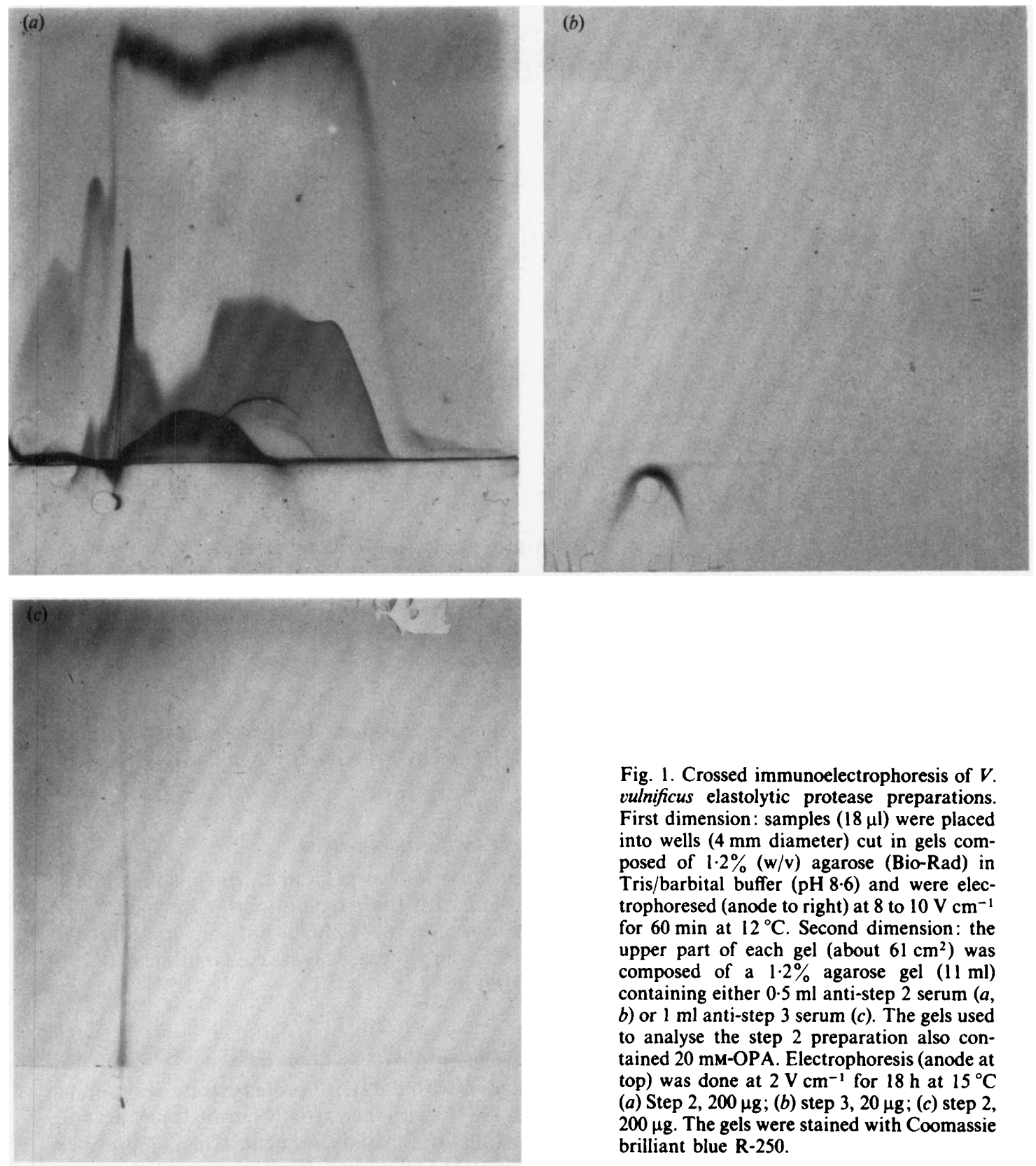

Fig. 1. Crossed immunoelectrophoresis of $V$. vulnificus elastolytic protease preparations. First dimension: samples $(18 \mu \mathrm{l})$ were placed into wells ( $4 \mathrm{~mm}$ diameter) cut in gels composed of $1.2 \%(\mathrm{w} / \mathrm{v})$ agarose (Bio-Rad) in Tris/barbital buffer ( $\mathrm{pH} \mathrm{8.6)}$ and were electrophoresed (anode to right) at 8 to $10 \mathrm{~V} \mathrm{~cm}^{-1}$ for $60 \mathrm{~min}$ at $12^{\circ} \mathrm{C}$. Second dimension: the upper part of each gel (about $61 \mathrm{~cm}^{2}$ ) was composed of a $1.2 \%$ agarose gel $(11 \mathrm{ml})$ containing either $0.5 \mathrm{ml}$ anti-step 2 serum $(a$, $b$ ) or $1 \mathrm{ml}$ anti-step 3 serum $(c)$. The gels used to analyse the step 2 preparation also contained 20 mM-OPA. Electrophoresis (anode at top) was done at $2 \mathrm{~V} \mathrm{~cm}^{-1}$ for $18 \mathrm{~h}$ at $15^{\circ} \mathrm{C}$ (a) Step 2, $200 \mu \mathrm{g}$; (b) step 3, $20 \mu \mathrm{g}$; (c) step 2, $200 \mu \mathrm{g}$. The gels were stained with Coomassie brilliant blue R-250.

\section{$M_{\mathrm{r}}$ and $P I$}

The $M_{\mathrm{r}}$ and $\mathrm{pI}$ of the step 3 protease (about 50500 and 5.7, respectively) were the same as the values previously determined (Kothary \& Kreger, 1985b) with the partially purified protease.

\section{Amino acid analyses}

Acidic, basic and nonpolar hydrophobic amino acid residues accounted for about 21,9 and $33 \%$ of the total residues, respectively (Table 2 ). The presence of four half-cystine residues suggests that the protease has two intra-chain disulphide bonds. Based on the $M_{\mathrm{r}}$ and the amino 


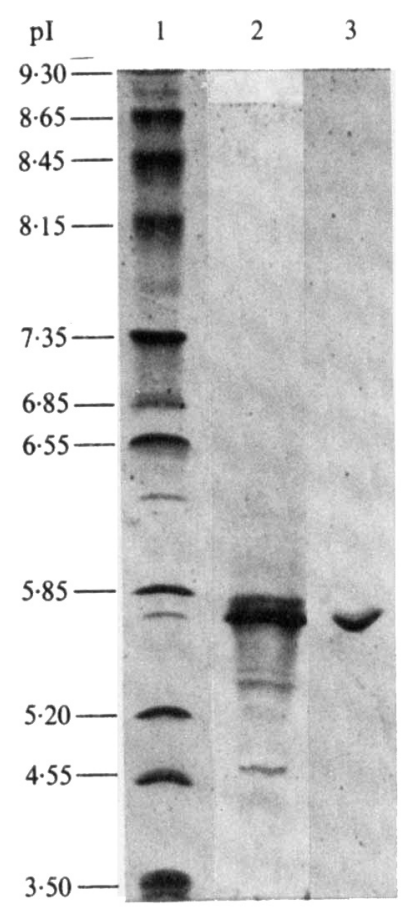

Fig. 2. Analytical thin-layer isoelectric focusing of $V$. vulnificus elastolytic protease preparations. The cathode was at the top of the gel. Lane 1, pI standards; lane 2, step 2 preparation $(40 \mu \mathrm{g})$; lane 3 , step 3 preparation $(10 \mu \mathrm{g})$. The gel was stained with Coomassie brilliant blue $\mathbf{R}-\mathbf{2 5 0}$.

acid concentrations, the enzyme has about 429 amino acid residues. The first 20 amino-terminal residues of the protease are Ala-Gln-Ala-Asn-Gly-Thr-Gly-Pro-Gly-Gly-Asn-Ser-Lys-Thr-GlyArg-Tyr-Glu-Phe-Gly.

\section{Determination of $\mathrm{pH}$ and temperature optima}

The $\mathrm{pH}$ optimum for caseinolytic and elastase activities was $\mathrm{pH} 7$ to 8 , which is the same as the value determined (Kothary \& Kreger, 1985b) with the partially purified enzyme. The temperature optimum for caseinolytic activity was 55 to $60^{\circ} \mathrm{C}$ (data not shown). Although activity was 3 -fold lower at $37^{\circ} \mathrm{C}$ than at 55 to $60^{\circ} \mathrm{C}$, the protease was assayed routinely at $37^{\circ} \mathrm{C}$ because activity was more stable at that temperature.

\section{Stability and inactivation studies}

The results of the stability and inactivation studies with the step 3 protease were very similar to those previously observed (Kothary \& Kreger, 1985b) with the partially purified enzyme, and, together with the $\mathrm{pH}$ optimum data, they suggest that the enzyme is a neutral metalloprotease. Also, the neutral pH optimum and the sensitivity to EDTA and OPA of our purified enzyme suggest that it is the same protease as that previously reported to be produced by $V$. vulnificus A8694 (Carruthers \& Kabat, 1981).

\section{Toxic activity}

The $\mathrm{LD}_{50}$ values for the step 3 protease by the intraperitoneal and intravenous routes were 11 units per mouse (about $1.5 \mathrm{mg} \mathrm{kg}^{-1}$ ) and 32 units per mouse (about $4.5 \mathrm{mg} \mathrm{kg}^{-1}$ ), respectively. Subcutaneous injection of 10 units $(40 \mu \mathrm{g})$ caused extensive dermonecrosis by $3 \mathrm{~h}$ postinjection. The activity of the enzyme in mice is consistent with the extensive dermonecrosis observed in naturally occuring and experimentally induced wound infections caused by $V$. vulnificus. A partially purified elastase preparation obtained from a different strain of $V$. vulnificus (B3547) 
(a)

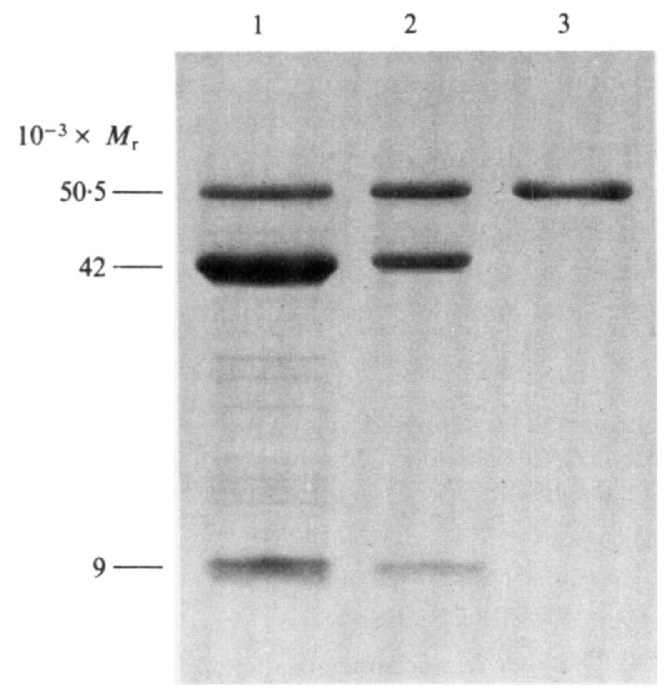

(b)

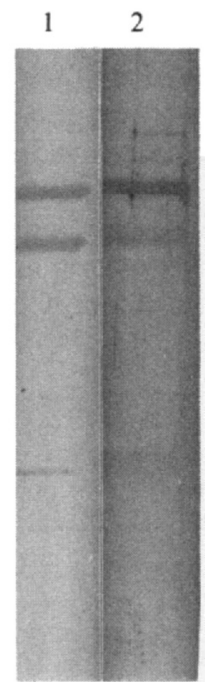

Fig. 3. SDS-PAGE and Western blot analysis of $V$. vulnificus elastolytic protease preparations. (a) SDSPAGE analysis. The cathode was at the top of the gel. Preparations in lanes 1 and 2 were denatured by heating with SDS before electrophoresis, and the preparation in lane 3 was inactivated and denatured at $4{ }^{\circ} \mathrm{C}$ with trichloroacetic acid and sulphosalicylic acid before heating with SDS and electrophoresis. All preparations were reduced with $\beta$-mercaptoethanol. Lane 1 , step $2(100 \mu \mathrm{g})$; lane 2, step $3(30 \mu \mathrm{g})$; lane 3 , step $3(30 \mu \mathrm{g})$. The gels were stained with Coomassie brilliant blue R-250. The estimated $M_{\mathrm{r}}$ values of the components in the stained bands in lanes 2 and 3 (as determined by the relative mobility method of Weber et al., 1972) are indicated. (b) Western blot analysis of a step 3 protease preparation $(15 \mu \mathrm{g})$ that was not inactivated at $4^{\circ} \mathrm{C}$ before heating with SDS and $\beta$-mercaptoethanol. Lane 1 , bands visible after staining with Amido black; lane 2, bands visible after sequential probing with rabbit antistep 3 serum, goat antirabbit IgG-horseradish peroxidase conjugate, and peroxidase substrate. The three bands observed by SDS-PAGE analysis $(a)$ do not coincide precisely with those observed by Western blot analysis $(b)$ because of uneven gel-swelling caused by the solvent used during the staining and destaining of the 4 to $30 \%(w / v)$ polyacrylamide gradient gel.

\section{Table 2. Amino acid composition of $V$. vulnificus elastolytic protease}

$\begin{array}{lcclcc}\text { Amino acid } & \begin{array}{c}\text { Concn found } \\ (\mathrm{mol} \%)\end{array} & \begin{array}{c}\text { No. of residues } \\ \text { per molecule } \\ \text { of protease* }\end{array} & \text { Amino acid } & \begin{array}{c}\text { Concn found } \\ (\mathrm{mol} \%)\end{array} & \begin{array}{c}\text { No. of residues } \\ \text { per molecule } \\ \text { of protease* }\end{array} \\ \text { Aspartic acid } & 15.47 & 68 & \text { Isoleucine } & 2.40 & 10 \\ \text { Threonine } & 7.64 & 33 & \text { Leucine } & 4.56 & 20 \\ \text { Serine } & 9.98 & 42 & \text { Tyrosine } & 6.91 & 31 \\ \text { Glutamic acid } & 5.42 & 24 & \text { Phenylalanine } & 4.60 & 21 \\ \text { Proline } & 3.12 & 13 & \text { Lysine } & 4.86 & 22 \\ \text { Glycine } & 10.80 & 41 & \text { Histidine } & 2.17 & 10 \\ \text { Alanine } & 8.89 & 36 & \text { Arginine } & 2.48 & 11 \\ \text { Valine } & 7.14 & 31 & \text { Half-cystine } & 0.88 & 4 \\ \text { Methionine } & 1.49 & 7 & \text { Tryptophan } & 1.17 & 5\end{array}$

* Based on an $M_{\mathrm{r}}$ of 50500

than we used also has been reported to be lethal and to produce dermonecrosis in mice (Poole et al., 1982).

In conclusion, the results of the studies described in this paper advance our knowledge concerning the elastolytic protease of $V$. vulnificus in three ways. First, we describe a simple scheme for obtaining large amounts of $V$. vulnificus elastase of rigorously documented purity. The availability of large amounts of the highly purified enzyme should help investigators 
examine the possible importance of the enzyme in the pathogenesis of diseases caused by $V$. vulnificus. Second, using the highly purified enzyme preparation, we confirmed the $M_{\mathrm{r}}, \mathrm{pI}, \mathrm{pH}$ optimum and stability data previously obtained (Kothary \& Kreger, 1985b) with a partially purified preparation of the enzyme. Contaminants can sometimes influence the physicochemical and pharmacological properties of biologically active proteins (Gray \& Kreger, 1985; Kothary \& Kreger, 1985a), so initial results obtained with preparations of undocumented homogeneity always should be re-examined using rigorously purified preparations. Third, we extended the information in our earlier publication (Kothary \& Kreger, 1985b) by reporting the amino acid composition and partial amino-terminal amino acid sequence of the enzyme, the temperature optimum of the enzyme, and some of the biological activities of the enzyme in mice.

We thank Dr Mark Lively (Protein Sequencing Laboratory, Oncology Research Center of the Bowman Gray School of Medicine ) and Dr Lowell Ericsson (AAA Laboratory, Mercer Island, Wash.) for amino acid analyses.

This investigation was supported by Public Health Service grant AI-18184 from the National Institute of Allergy and Infectious Diseases.

\section{REFERENCES}

Amako, K., OKada, K. \& Miake, S. (1984). Evidence for the presence of a capsule in Vibrio vulnificus. Journal of General Microbiology 130, 2741-2743.

andrus, C. R., Walter, M., Crosa, J. H. \& Payne, S. M. (1983). Synthesis of siderophores by pathogenic Vibrio species. Current Microbiology 9, 209-214.

BRADFORD, M. M. (1976). A rapid and sensitive method for the quantitation of microgram quantities of protein utilizing the principle of protein-dye binding. Analytical Biochemistry 72, 248-254.

CARRUTHERS, M. M. \& KABAT, W. J. (1981). Isolation, purification and characterization of protease from Beneckea vulnifica (lactose-positive vibrio, Vibrio vulnificus). Abstracts of the Annual Meeting of the American Society for Microbiology 81, 24.

Gardi, C. \& Lungarella, G. (1984). Detection of elastase activity with a zymogram method after isoelectric focusing in polyacrylamide gel. Analytical Biochemistry 140, 472-477.

Gray, L. D. \& KREger, A. S. (1985). Purification and characterization of an extracellular cytolysin produced by Vibrio vulnificus. Infection and Immunity 48 , $62-72$.

HARBOE, M. \& Closs, O. (1983). Immunization with precipitates obtained by crossed immunoelectrophoresis. In Handbook of Immunoprecipitation-in-Gel Techniques, pp. 353-359. Edited by N. H. Axelsen. Oxford: Blackwell Scientific Publications.

Høiby, N. \& AXelsen, N. H. (1983). Crossed immunoelectrophoresis as modified for quantitative purposes. In Handbook of Immunoprecipitation-in-Gel Techniques, pp. 125-134. Edited by N. H. Axelsen. Oxford: Blackwell Scientific Publications.

KOTHARY, M. H. \& KReger, A. S. (1985a) Purification and characterization of an extracellular cytolysin produced by Vibrio damsela. Infection and Immunity 49, 25-31.

Kothary, M. H. \& Kreger, A. S. (1985b). Production and partial characterization of an elastolytic protease of Vibrio vulnificus. Infection and Immunity 50, 534-540.

Kreger, A. S. \& Gray, L. D. (1978). Purification of Pseudomonas aeruginosa proteases and microscopic characterization of pseudomonal protease-induced rabbit corneal damage. Infection and Immunity 19, 630-648.

KREGer, A. \& LoCKWOOD, D. (1981). Detection of extracellular toxin(s) produced by Vibrio vulnificus. Infection and Immunity 33, 583-590.

Kreger, A., DeChatelet, L. \& Shirley, P. (1981). Interaction of Vibrio vulnificus with human polymorphonuclear leukocytes: association of virulence with resistance to phagocytosis. Journal of Infectious Diseases 144, 244-248.

Kreger, A. S., Gray, L. D. \& Testa, J. (1984). Protection of mice against Vibrio vulnificus disease by vaccination with surface antigen preparations and anti-surface antigen antisera. Infection and Immunity 45, 537-543.

LAEMMLI, U. K. (1970). Cleavage of structural proteins during the assembly of the head of bacteriophage T4. Nature, London 227, 680-685.

LYeRLY, D. \& KREger, A. (1979). Purification and characterization of a Serratia marcescens metalloprotease. Infection and Immunity 24, 411-421.

MORRIS, J. G., JR \& BLACK, R. E. (1985). Cholera and other vibrioses in the United States. New England Journal of Medicine 312, 343-350.

POOLE, M. D., BOWDRE, J. H. \& KLAPPER, D. (1982). Elastase produced by Vibrio vulnificus : in vitro and in vivo effects. Abstracts of the Annual Meeting of the American Society for Microbiology 82, 43.

REED, L. J. \& MUENCH, H. (1938). A simple method of estimating fifty percent endpoints. American Journal of Hygiene 27, 493-497.

Simpson, L. M. \& Oliver, J. D. (1983). Siderophore production by Vibrio vulnificus. Infection and Immunity 41, 644-649.

Smith, G. C. \& Merkel, J. R. (1982). Collagenolytic activity of Vibrio vulnificus: potential contribution to its invasiveness. Infection and Immunity 35, 11551156.

Testa, J., Daniel, L. W. \& Kreger, A. S. (1984). Extracellular phospholipase $A_{2}$ and lysophospholipase produced by Vibrio vulnificus. Infection and Immunity 45, 458-463. 
Tison, D. L. \& Kelly, M. T. (1984). Vibrio species of medical importance. Diagnostic Microbiology and Infectious Diseases 2, 263-276.

Towbin, H., Staehlin, T. \& Gordon, J. (1979). Electrophoretic transfer of proteins from polyacrylamide gels to nitrocellulose sheets: procedures and some applications. Proceedings of the National Academy of Sciences of the United States of America 76, 4350-4354.

WALlENBORG, B. \& ANDERSSON, U.-B. (1978). Immunoelectrophoretic techniques with the LKB 2117 Multiphor. LKB Application Note 249. Bromma: LKB Produkter AB.
Weber, K., Pringle, J. R. \& Osborn, M. (1972). Measurement of molecular weights by electrophoresis on SDS-acrylamide gel. Methods in Enzymology 26, 3-27.

Wickboldt, L. G. \& SANDERS, C. V. (1983). Vibrio vulnificus infection. Case report and update since 1970. Journal of the American Academy of Dermatology 9, 243-251.

Yoshida, S.-I., OGawa, M. \& Mizuguchi, Y. (1985). Relation of capsular materials and colony opacity to virulence of Vibrio vulnificus. Infection and Immunity 47, 446-451. 